\title{
IN VITRO PHARMACOLOGICAL EVALUATION OF GALIUM ELEGANS: PHYTOCHEMICAL, ANTIOXIDANT, BIOFILM INHIBITION AND CYTOTOXICITY POTENTIAL
}

\author{
TAHIR ZAMAN ${ }^{1}$, MUHAMMAD IRSHAD $^{2}$, MUHAMMD FARAZ KHAN $^{3}$, ANSAR \\ MEHMOOD $^{3 *}$, IMTIAZ HUSSAIN ${ }^{4}$, MAJID MAHMOOD ${ }^{5}$ \\ ${ }^{1}$ Department of Chemistry, University of Poonch Rawalakot, 12350, Azad Jammu and Kashmir, Pakistan \\ ${ }^{2}$ Department of Chemistry, University of Kotli Azad Jammu and Kashmir, 11100, Azad Jammu and Kashmir, Pakistan \\ ${ }^{3}$ Department of Botany, University of Poonch Rawalakot, 12350, Azad Jammu and Kashmir, Pakistan \\ ${ }^{4}$ Department of Food Science and Technology, University of Poonch Rawalakot (UPR), 12350, Azad Kashmir, Pakistan \\ ${ }^{5}$ Department of Zoology, University of Poonch Rawalakot, 12350, Azad Jammu and Kashmir, Pakistan
}

*corresponding author: ansar.mehmood321@gmail.com

Manuscript received: January 2021

\begin{abstract}
Ethnomedicinally, Galium elegans is a valuable species used to cure many indigenous ailments in Asia. This study explored the phytochemical, antioxidant, biofilm inhibition and cytotoxic properties of G. elegans extracts. The results showed that the ethanol extract was enriched in phenolic contents $(151.12 \pm 0.02 \mathrm{mg} \mathrm{GAE} / \mathrm{g})$ and demonstrated potent antioxidant activity (IC 50 $57.95 \mu \mathrm{g} / \mathrm{mL}$ ). Biofilm inhibition of $E$. coli showed that petroleum ether extract was more potent in the inhibition of biofilm $(65.75 \pm 0.3 \%)$. The nominal cytotoxicity of all the tested crude extracts ranged from $12.02 \pm 0.40$ to $32.03 \pm 0.64 \%$, revealed its safe usage as ethnomedicine. In thrombolytic study, only the acetone extract showed a very small anti-fibrinogen potential $(3.07 \pm 0.25)$. In conclusion, G. elegans qualifies preliminary in vitro evaluation as a potential source for antioxidant and biofilm inhibitory compounds. These findings license additional investigation to separate major bio-compounds from the extracts of G. elegans.
\end{abstract}

\section{Rezumat}

Galium elegans este o specie utilizată în medicina tradițională din Asia. Acest studiu a evaluat proprietățile fitochimice, antioxidante, de inhibare a biofilmului și proprietătile citotoxice ale extractelor de G. elegans. Rezultatele au arătat că extractul etanolic a fost bogat în constituenți fenolici $(151,12 \pm 0,02 \mathrm{mg} \mathrm{GAE} / \mathrm{g})$ și a demonstrat o activitate antioxidantă puternică (IC 50 $57,95 \mu \mathrm{g} / \mathrm{mL})$ iar extractul în eter de petrol a fost mai eficient în inhibarea biofilmului $(65,75 \pm 0,3 \%)$. Citotoxicitatea nominală a tuturor extractelor brute testate a variat de la 12,02 $\pm 0,40$ la 32,03 $\pm 0,64 \%$. În studiul trombolitic, doar extractul în acetonă a arătat un potențial antifibrinogenic foarte mic $(3,07 \pm 0,25)$. În concluzie, $G$. elegans reprezintă o sursă potențială de compuși antioxidanți și inhibitori ai biofilmelor și sunt necesare investigații suplimentare pentru a separa bio-compuşii majori din extractele de G. elegans.

Keywords: phytochemical analysis; antioxidant; antimicrobial; cytotoxicity; thrombolytic potential

\section{Introduction}

Oxidative stress is a leading cause of many diseases. Usually, it is caused due to difference between production and elimination of reactive oxygen species (ROS). Cells normally use endogenous antioxidants to quench ROS; however, over production of ROS can harm cellular constituents [37]. Several synthetic antioxidants are also available for this purpose, but there is a serious concern of negative health effects related to the use of synthetic antioxidants [15]. For example, synthetic antioxidants like butylated hyroxyanisole and butylated hydrozytoluene have shown carcinogenic activity $[21,22]$. In contrast to these, natural antioxidants in the form of phenols showed health friendly biological activities in human [46]. A large number of polyphenolics such as phenols and flavonoids have been identified so far, having diverse biological activities including antioxidant, antimicrobial, anticancer, and anti-inflammatory activities [25, 33]. Physiological and pharmacological properties of phenols depend largely upon their ability to scavenge free radicals [6]. Moreover, flavonoids also have the ability to transfer free radicals owing to their antioxidant activity and inhibition of enzymes oxidases [12, 17, 18]. In addition to synthetic antioxidants, synthetic antibiotics have also shown serious health concerns in human. The major drawback of synthetic antibiotics is the onset of resistance in microorganisms. Hence, this antibiotics are gradually being replaced by natural products with antibacterial effects [7, 28, 42]. In this regard, the discovery of medicinal plants with natural pharmacological activities is a need of the time for a better human health. 
Galium L. is the largest genus of family Rubiaceae, with about 667 species distributed worldwide. It is characterized by numerous traits: usually subshrubs to perennial or annual herbs [52]. Pharmacologically, various species of this genus have been reported for biological activities i.e., G. verum L. is reported for immunomodulatory activity [47] and G. aparine L. is reported for antimicrobial, antioxidant and anticancer activities [4]. Galium elegans Wall. ex Roxb., locally known as booti pneumonia, is commonly distributed in the Himalayan region of Pakistan and Azad Jammu and Kashmir. Despite of its medicinal significance and traditional folklore, the plant is still not investigated for its pharmacological characteristics. Locally, Galium has many traditional uses i.e. root extract is used to treat pneumonia in children and whole plant is used as diuretic, blood cleanser and to remove kidney stones [9]. The paste of the plant is used as wound healing and to cure rheumatoid arthritis [13]. In this context, we have studied the in vitro pharmacological activities such as antioxidant, biofilm inhibition, cytotoxic and phytochemical screening of Galium elegans to sustenance further exploration of this plant for therapeutic purpose. As we know, this is the first study in this background.

\section{Materials and Methods}

\section{Collection}

The whole plant of $G$. elegans was collected from Northern Pakistan (latitude 33 $51^{\prime} 32.18^{\prime \prime N}$, longitude $73^{\circ} 45^{\prime} 34.93 " \mathrm{E}$, elevation of 5374 feet). The plant was identified by a taxonomist Dr. Sajjad Hussain, and voucher specimen (UPR-Poonch 1112) was submitted to Herbarium, Department of Botany, University of Poonch Rawalakot. A sample of $G$. elegans was pressed, mounted on Herbarium sheet and deposited in the Herbarium.

Extraction of plant material

Ethanol (1.5 L) (Merk) was used initially to make the extraction of plant material. A $25 \mathrm{~g}$ fine powder of plant material was soaked in $100 \mathrm{~mL}$ of solvent (ethanol) for three days at room temperature. The extract was than filtered using Whatman filter paper no. 42. The filtrate was further evaporated using rotary evaporator into dried, crude ethanolic extract (EE). The same methodology was used to get the chloroform, petroleum ether and aqueous extracts named as CE, PEE and AE, respectively. Water soluble layer was freeze-dried to obtain aqueous fraction. For performing different bioassays and phytochemical analysis, these extracts were stored at $4^{\circ} \mathrm{C}$.

Yield of extract

The obtaining yield of each extract was calculated by using formula (A).

$$
\begin{aligned}
& \text { Yeild }(\%)=\frac{\text { weight of powdered extract }(\mathrm{g})}{\text { weight of dried sample }(\mathrm{g})} \times 100,(\mathrm{~A}) \mathrm{.} \\
& \qquad \% \text { inhibition activity }=\frac{\text { Absorbance of control-Absorbance of sample }}{\text { Absorbance of control }} \times 100,
\end{aligned}
$$

\section{Phytochemical screening}

For preliminary phytochemical analysis, plant extracts were evaluated for the presence or absences of tannins, saponins, alkaloids, glycosides, tri terpenoids, steroids, flavonoids and carbohydrates by using previously described methods $[19,26]$.

Total phenolic content (TPC)

The TPC of each extract was measured by using the Folin-Ciocâlteu reagent method with certain modifications [11]. The methanolic solution of each crude $(1 \mathrm{mg} / \mathrm{mL})$ extract was used for analysis. An aliquot of $0.5 \mathrm{~mL}$ of each extract was mixed with $2.5 \mathrm{~mL}$ of $10 \%$ FolinCiocâlteu reagent (in water) and kept in dark. After $5 \mathrm{~min}, 2.5 \mathrm{~mL}$ of $6 \%$ sodium carbonate was added in the mixture and allowed to stand for $90 \mathrm{~min}$ at room temperature. The absorbance of each reaction mixture was measured at $750 \mathrm{~nm}$. Gallic acid (GA) was used as a standard and a calibration curve was prepared in the range of $0-200 \mu \mathrm{g} / \mathrm{mL}$. The results were expressed as $\mathrm{mg}$ gallic acid equivalent (GAE) per gram of extract. Total flavonoid content (TFC)

Aluminum chloride colorimetric method with some modifications [49] was used to calculate the total flavonoid content with catechin as a standard. Briefly, $1 \mathrm{~mL}$ of the plant extract was mixed with $4 \mathrm{~mL}$ of distilled water followed by the addition of $0.3 \mathrm{~mL} 10 \%$ $\mathrm{ALCl}_{3}$ and $0.3 \mathrm{~mL} \mathrm{5 \%} \mathrm{NaNO}_{3}$. After the incubation of $6 \mathrm{~min}, 2 \mathrm{~mL}$ of $1 \mathrm{M}$ sodium hydroxide was added, and the final volume was made up to $10 \mathrm{~mL}$ with deionized waster. The absorbance of each reaction was measured at $530 \mathrm{~nm}$ after $15 \mathrm{~min}$ of incubation at room temperature. The calibration curve for catechin in the range of $0-200 \mu \mathrm{g} / \mathrm{mL}$ was prepared in the same manner and TFC was expressed as mg catechin equivalent (CAE) per gram of extract.

Antioxidant activity

The antioxidant activity was determined as ability of the extracts to scavenge free radicals through 2, 2-diphenyl-1-picrylhydrazyl (DPPH) assay as previously described by [1] with some modifications. In brief, $1 \mathrm{M}$ DPPH solution was prepared as a stock and stored at $-20^{\circ} \mathrm{C}$ until further use. A series of concentrations in the range of $25-250 \mu \mathrm{g} / \mathrm{mL}$ was prepared for each extract. For \% inhibition activity, $1.5 \mathrm{~mL}$ of each concentration was placed in different test tubes and $1.5 \mathrm{~mL}$ DPPH working solution was added. After 30 min of incubation in the dark, absorbance was measured at $517 \mathrm{~nm}$. The absorbance of a blank (1.5 mL DPPH + $1.5 \mathrm{~mL}$ methanol) was also measured at a same wavelength. The \% inhibition activity was calculated using equation (B).

$\mathrm{IC}_{50}(\mu \mathrm{g} / \mathrm{mL})$ value was calculated for each extract, which was used to assess the antioxidant activity of the extracts. All the testes were carried out in triplicates. 
Biofilm inhibitory activity

Escherichia coli, a well-known bacterium for colonization on human associated surfaces and medical devices, was obtained for the biofilm inhibition effect of Galium elegans fractions. The strain was cultured at $37^{\circ} \mathrm{C}$ and maintained on nutrient agar slant at $4^{\circ} \mathrm{C}$. For biofilm inhibition assay, a microtitration method was used with 96-well plates. The wells were treated in according a predefined plate layout where all the fractions were applied to diluted bacterial cultures at a concentration of $100 \mu \mathrm{g} / \mathrm{mL}$ with a final well volume of $220 \mu \mathrm{L}$. Nutrient broth was taken as negative control, while antibiotic drug rifampicin was taken as positive control. The plates were incubated at $37^{\circ} \mathrm{C}$ for $24 \mathrm{~h}$. After$$
\text { Minimum Biofilm Inhibitory Concentration }(\mathrm{MBIC})=\frac{100-\mathrm{OD}_{630} \text { sample }}{\mathrm{OD}_{630} \text { control }} \times 100 \text {, }
$$

incubation, the well plates were washed with sterile phosphate buffer thrice to remove all non-adherent bacteria. Then the emptied wells were filled with equal volume of methanol and left for half an hour so that biofilms (if formed in any triplicate could be fixed). The plates were stained with crystal violet dye for 25 min and treated with $33 \%$ (v/v) glacial acetic acid to ensure that dye has essentially bonded with biofilms. Treated plates were loaded to a microtiter plate reader (Biotech, USA) and optical density (OD) was measured at $630 \mathrm{~nm}$ (BioTek, USA). All the tests were carried thrice times against both selected bacterial strain and the results were averaged [45]. The biofilm inhibition was measured using formula $(\mathrm{C})$.

thrombolytic activity was determined using the formula (D).

\section{Hemolytic activity}

Fresh heparinized bovine blood $(3 \mathrm{~mL})$ was collected from the Department of Clinical Medicine and Surgery, University of Agriculture, Faisalabad, Pakistan. Blood was centrifuged for $5 \mathrm{~min}$ at $1000 \mathrm{x} \mathrm{g}$, the plasma obtained was discarded, and the cells were washed thrice with $5 \mathrm{~mL}$ chilled $\left(4^{\circ} \mathrm{C}\right)$ sterile isotonic phosphatebuffered saline ( $\mathrm{pH} 7.4)$. The cells were maintained at a confluence of more than $80 \%$. The standardized cells were re-suspended in fresh media using flat bottom 96-well plates (Thermo Fisher Scientific) and treated with ethanolic, chloroform, petroleum ether and aqueous fractions of G. elegans at room temperature. Phosphatebuffered saline (PBS) was taken as negative control while the triton $\mathrm{X}-100$ was taken as positive control and pass through the same process. After treatment, the cells were incubated and agitated for $10 \mathrm{~min}$ and then the treated plates were centrifuged for 5 minutes at 1000x g and were placed over an ice block. From each tube, the supernatant of $100 \mu \mathrm{L}$ was taken and diluted 10 times with chilled PBS. The optical density was measured at $576 \mathrm{~nm}$ using uQuant (Biotech, USA). The calculation was made at the end for \% RBCs lysis for each sample [44].

\section{Thrombolytic activity}

Venous blood from five volunteer was acquired and incubate at $37^{\circ} \mathrm{C}$ for $40 \mathrm{~min}$. Five different pre-weighed sterile micro centrifuge tube were used to take $5 \mathrm{~mL}$ of blood sample. From each centrifuge tube, the fluid was completely released after 175 clot formation and the clot weight was determined by subtracting weight of clot containing tube from weight of tube alone. The cells clots were exposed to all four fractions of Galium elegans where $100 \mu \mathrm{L}$ of each treatment was applied to the clots formed in a blood volume of 5 $\mathrm{mL}$. Thrombolytic enzyme streptokinase was used as positive control whereas distilled water was the negative control. The centrifuge tubes with the treatment and control were incubated for an hour at room temperature. The cellular contents released due to lysis was carefully separated and tubes were weighed again [38]. Overall

$$
\% \text { Clot Lysis }=\frac{\mathrm{wt} \text { of released clot }}{\text { clot } \mathrm{wt}} \times 100 \text {, }
$$

\section{Results and Discussion}

\section{Yield of the extract}

The extraction of phytochemicals in different solvents is based on the solubility of these phytochemicals in solvents. The ethanol extract gained high extraction yield $(15.21 \pm 0.2 \% \mathrm{w} / \mathrm{w})$ as compared to other solvents (Table I). The lowest extraction yield was obtained with petroleum ether $(3.08 \pm 0.3 \% \mathrm{w} / \mathrm{w})$. The ascending order of the extraction yield in different solvents was as ethanol $>$ aqueous $>$ chloroform $>$ petroleum ether. Phytoconstituents have variable solubility based on the polarity of extraction solvents, thus biological activity of a plant it generally depends upon the type of extraction solvent [2].

Table I

Preliminary phytochemical screening for the presence of different bio-compounds in the extracts of G. elegans

\begin{tabular}{lcccc}
\hline & EE & CE & PEE & AE \\
\hline Alkaloids & + & + & + & + \\
Flavonoids & + & + & + & + \\
Glycosides & + & + & + & + \\
Saponins & + & + & + & + \\
Steroids & - & - & - & - \\
Tannins & + & + & + & + \\
Ttriterpenoids & + & + & + & - \\
Carbohydrates & - & - & - & - \\
Protein & + & + & - & + \\
Amino acid & + & - & - & + \\
Polyphenols & + & + & + & + \\
\hline
\end{tabular}

$\mathrm{EE}=\overline{\text { ethanol extract } ; \mathrm{CE}=\text { chloroform extract } ; \mathrm{PEE}=\text { petroleum }}$ ether extract; $\mathrm{AE}=$ aqueous extract; " + " = presence of phytochemicals, "-" = absence of phytochemicals

\section{Phytochemical screening}

Preliminary phytochemical screening for the presence of different phytochemicals in different extracts of $G$. elegans is shown in Table II. The TPC and TFC were 
also determined in each extract (Table III). The EE showed more TPC (151.12 $\pm 0.02 \mathrm{mg} \mathrm{GAE} / \mathrm{g})$ followed by PEE ( $37.31 \pm 0.15 \mathrm{mg} \mathrm{GAE} / \mathrm{g})$. The maximum TFC were found in PEE $(140.21 \pm 0.1 \mathrm{mg} \mathrm{CAE} / \mathrm{g})$ followed by $\mathrm{CE}(115.11 \pm 0.1 \mathrm{mg} \mathrm{CAE} / \mathrm{g})$. The presence of different phytochemicals are the reasons to have great medicinal values of this plant. For example, alkaloids are well known as powerful poison and plants derived alkaloids have many biological applications such as antimicrobial, antiplasmodial, anti-inflammatory and cytotoxic activity $[5,8,16,48]$.

Table II

Yield of the extract, bioactive compounds and antioxidant activity of G. elegans extracts

\begin{tabular}{lcccc}
\hline & Yield of extract & TPC & TFC & Antioxidant acidity by DPPH \\
\cline { 5 - 5 } & $(\% \mathrm{w} / \mathrm{w})$ & $(\mathrm{mg} \mathrm{GAE} / \mathrm{g})$ & $(\mathrm{mg} \mathrm{CAE} / \mathrm{g})$ & $\mathrm{IC} 50(\mu \mathrm{g} / \mathrm{mL})$ \\
\hline $\mathrm{EE}$ & $3.08 \pm 0.3$ & $151.12 \pm 0.02$ & $55.18 \pm 0.15$ & 57.95 \\
$\mathrm{CE}$ & $8.94 \pm 0.1$ & $27.10 \pm 0.2$ & $115.11 \pm 0.1$ & 150.26 \\
$\mathrm{PEE}$ & $15.21 \pm 0.2$ & $37.31 \pm 0.15$ & $140.21 \pm 0.1$ & 88.54 \\
$\mathrm{AE}$ & $14.92 \pm 0.4$ & $30.73 \pm 0.3$ & $40.11 \pm 0.13$ & 107.58 \\
\hline
\end{tabular}

The values are means \pm standard error of means $(\mathrm{n}=3)$; $\mathrm{EE}=$ ethanol extract; $\mathrm{CE}=$ chloroform extract; $\mathrm{PEE}=$ petroleum ether extract; $\mathrm{AE}=$ aqueous extract $; \mathrm{PTC}=$ total phenolic content; $\mathrm{TFC}=$ total flavonoid content

Table III

Cytotoxicity in the form of clot lysis (\%) and thrombolytic activity (\%) of G. elegans extracts

\begin{tabular}{lcc}
\hline & Clot lysis $(\%)$ & Thrombolytic activity $(\%)$ \\
\hline EE & $21.06 \pm 0.12$ & $1.06 \pm 0.15$ \\
CE & $32.03 \pm 0.64$ & $2.03 \pm 0.25$ \\
PEE & $12.02 \pm 0.40$ & $3.07 \pm 0.2$ \\
AE & $27.05 \pm 0.75$ & $1.03 \pm 0.02$ \\
Streptokinase & $87.02 \pm 0.12$ & $98.06 \pm 0.2$ \\
Distilled water & $2.01 \pm 0.20$ &
\end{tabular}

The values are means \pm standard error of means $(\mathrm{n}=3)$; $\mathrm{EE}=$ ethanol extract; $\mathrm{CE}=$ chloroform extract; $\mathrm{PEE}=$ petroleum ether extract; $\mathrm{AE}=$ aqueous extract

The recognition of high amount of phenolic contents in the $\mathrm{EE}$ of $G$. elegans clues that this plant has significant antioxidant activity. Phenolics are the major component of non-enzymatic antioxidant system of the cells, because of their unique structural features [41]. The capacity of phenol extraction depends upon the methods and solvents applied, so ethanol received more phenols than chloroform, petroleum ether and water extract $[31,35]$. Like the phenols, flavonoids have also significant importance in living system. They are reported to have antimicrobial, antithrombotic, antiallergic, anticancer and antioxidant activities $[3,51]$. The flavonoids trigger their action by inhibition the membranous enzymes like ATPase and phospholipase and by effecting the permeability of membranes [29].

Antioxidant activity

Plant based antioxidants have a vital role in improving the damaging effects of oxidative stress produced by ROS. A solid relationship exists between the pathogens and a degree of oxidative stress; therefore, the practice of plant-based antioxidants is reflected as an effective therapeutic tactic against numerous infectious diseases [32]. In this study, the DPPH assay was used to demonstrate the \% scavenging activity of four extracts of $G$. elegans and the antioxidant activity was observed in the form of $\mathrm{IC}_{50}$ value, which corresponds to the concentration of extracts that are able to scavenge $50 \%$ of free radicals present in the reaction mixture. Higher $\mathrm{IC}_{50}$ value represents the low antioxidant activity. In our results, the maximum antioxidant activity was shown by $\mathrm{EE}$ as it has least $\mathrm{IC}_{50}$ of $57.95 \mu \mathrm{g} / \mathrm{mL}$ in DPPH scavenging assay. These results can be elucidated by the high amount of phenolics in the EE of G. elegans in comparison with chloroform, petroleum ether and aqueous extract, and these phenolics were found to have strong association with antioxidant activity [36]. Moreover, a positive correlation $(\mathrm{r}=0.787)$ between the phenolic contents and antioxidant activity further supports the idea that phenols are main phytochemicals involve in antioxidant activity. It is already known that antioxidant ability of plant extracts attributes to the TPC and TFC of the extracts [24, 30]. In detail, a particular structure of phenols allows them to give hydrogen, de-confine electrons, reduce singlet oxygen and react with free radicals $[39,40]$. Flavonoids are also reported to have good antioxidant activity [51]. Our results are in good accordance with the findings that ethanol extract of Aloe vera leaf has more antioxidant activity than n-hexane and aqueous extract [20, 43].

\section{Biofilm inhibition}

Biofilm is actually surface-associated microbial communities that can tolerate high concentrations of antimicrobials by physically preventing occluding drug entry via the biofilm matrix [50]. This can lead to a risk of resistance in microbial growth up to many folds against conventional antimicrobial agents. Inhibiting the production of biofilms, then, would allow biofilm-associated infections in order to be more easily resolved with antibiotic treatment. E. coli is a highly 
versatile bacterium ranging from harmless gut commensal to intra- or extra- intestinal pathogens, including common colonizers of medical devices and the primary causes of recurrent urogenital infections [23]. To date, the mechanisms of action of the known anti-biofilm compounds may involve the inhibition of the bacterial adhesion, which is considered the initial steps in bacterial pathogenesis [10]. Herein we investigated the effect of EE, CE, PEE and AE of G. elegans against biofilm formation in E. coli. The results of biofilm inhibition activity are shown in Figure 1, where highest biofilm inhibition is shown by PEE $(65.75 \pm 0.3 \%)$ followed by $\mathrm{CE}(41.17 \pm 0.2 \%)$ among the extracts.

Microscopic visualization of PEE (Figure 2) illustrates a significant disruption of biofilm formed by $E$. coli as compare to negative control. It is observed that PEE attained more than $50 \%$ biofilm inhibition at a concentration of $100 \mu \mathrm{g} / \mathrm{mL}$. Previously, medicinal plants such as Origanum majorana and Thymus zygis were reported from Saudi Arabia for significant biofilm inhibition against E. coli isolates [27].

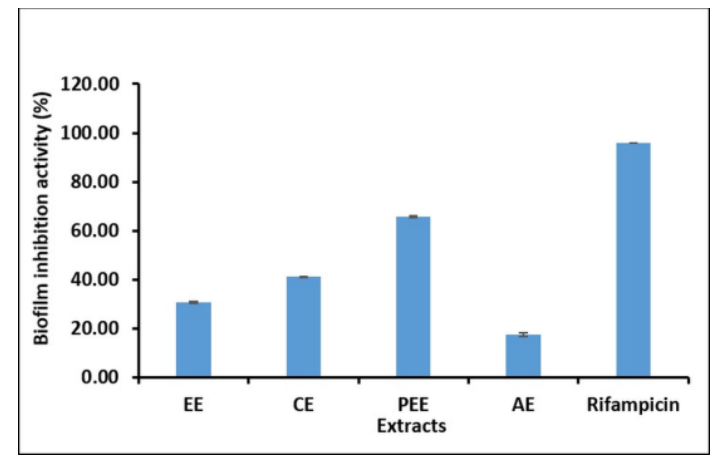

Figure 1.

Biofilm inhibition activity (\%) of G. elegans extracts against $E$. coli

The values are means \pm standard error of means $(n=3)$, EE ethanol extract, $\mathrm{CE}$ chloroform extract, PEE petroleum ether extract, $\mathrm{AE}$ aqueous extract
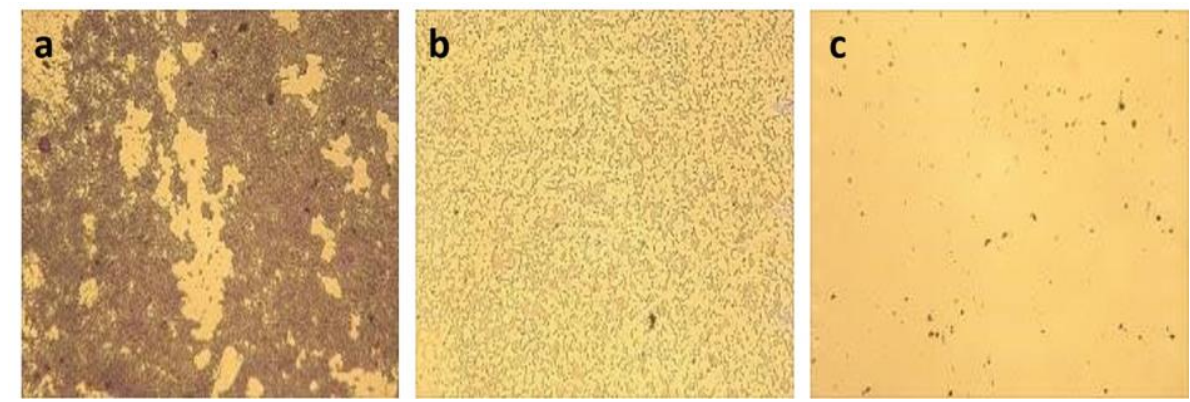

Figure 2.

Microscopic images of biofilm inhibition of E. coli: a) Negative control (Nutrient broth only), b) Rifampicin (positive control) and c) Petroleum ether extract of G. elegans

It was noted that organic fraction particularly PEE was more effective carrier for anti-biofilm agents. Similar findings were reported previously where crude extract of Lawsonia inermis in petroleum ether inhibited biofilm formation up to $80 \%$ at concentration of 256 $\mu \mathrm{g} / \mathrm{mL}$.

Cytotoxicity

Toxicity of the active molecule is a key factor during drug designing and development. Assessing cytotoxicity is, therefore, inevitable to draw information on the interaction between molecules and biological entities at cellular level [34]. Hemolytic activity for example is a key measure to gauge general cytotoxicity towards normal healthy cells [14]. The cytotoxic activity was measured in the form of hemolytic (clot lysis) and thrombolytic activity. The results of hemolytic activity indicated that $\mathrm{CE}$ had a higher percentage of clot lysis $(32.03 \pm 0.64 \%)$ than all other extract, but significantly very low when compared with control $(87.02 \pm 0.12 \%)$, as shown in Table III. To validate the argument, the extract fractions were also applied to blood clots formed in vitro from venous blood of human volunteers. It was recorded that, none of the extract fractions could reach even a minimal level of lytic activity as compared to the control (Table III). This has ruled out the potential of chloroform fraction as cytotoxic agent which showed a modest hemolytic effect previously. It is important to note that chloroform has cytotoxic effects against living cells as it dissolves lipid bilayer, therefore hemolytic activity of chloroform fraction is more likely due to the toxicity of chloroform as solvent. Previous studies have reported chloroform fraction as the most cytotoxic against cancer cell lines [2].

\section{Conclusions}

In conclusion, this research shows the presence of several phytochemicals such as tannins, saponins, alkaloids, glycosides, triterpenoids, steroids, flavonoids and carbohydrates in the EE, CE, PEE and AE of $G$. elegans. These extracts have also showed significant antioxidant and antibacterial activities, can be attributed to the phenolic and flavonoids content present in the extracts. However, the phytochemicals profile and biological activities are dependent on the polarity of the extraction solvents. The EE received the higher TPC and PEE received the higher TFC. Similarly, EE extract showed the higher antioxidant potential by 
DPPH assay and PEE showed the higher antibacterial activity by biofilm inhibition assay against $E$. coli. These extracts were further investigated for their cytotoxic effect against normal cells and found to be safe with minimal toxic effect. Hence, this study is directed towards the targeted isolation of bioactive compounds and evaluation of their pharmacological activity and mechanism of action.

\section{Acknowledgement}

Authors are obliged to Higher Education Commission of Pakistan (HEC) for funding and the University of Agriculture Faisalabad and the Department of Agriculture University of Poonch Rawalakot for the provision of lab facilities.

\section{Conflict of interest}

The authors declare no conflict of interest.

\section{References}

1. Abdul-Wahab NZ, Shahar S, Abdullah-Sani H, Pihie AHL, Ibrahim N, Antioxidant, antibacterial and antiviral properties of Goniothalamus umbrosus leaves methanolic extract. Afr J Microbiol Res., 2011; 5(20): 3138-3143.

2. Ahmed M, Fatima H, Qasim M, Gul B, Polarity directed optimization of phytochemical and in vitro biological potential of an indigenous folklore: Quercus dilatata Lindl. ex Royle. BMC Compl Altern Med., 2017; 17(1): 386: 1-16.

3. Alam F, Suleman S, Study of phytochemistry and antioxidant activity of Hertia intermedia (Boiss.) flowers of Balochistan. Lasbela, U J Sci Techl., 2015; 92-100.

4. Al-Snafi AE, Chemical constituents and medical importance of Galium aparine - A review. IAJPS, 2018; 5: 1739-1744.

5. Ameyaw Y, Duker-Eshun G, The alkaloid contents of the ethno-plant organs of three antimalarial medicinal plant species in the eastern region of Ghana. Int J Chem Sci., 2009; 7(1): 48-58.

6. Baidez AG, Gomez P, Del, Rio JA, Ortuno A, Dysfunctionality of the xylem in Olea europaea L. plants associated with the infection process by Verticillium dahliae Kleb. Role of phenolic compounds in plant defense mechanism. J Agri Food Chem., 2007; 55(9): 3373-3377.

7. Bamoniri A, Ebrahimabadi AH, Mazoochi A, Behpour M, Kashi FJ, Batooli H, Antioxidant and antimicrobial activity evaluation and essential oil analysis of Semenovia tragioides Boiss. from Iran. Food Chem., 2010; 122(3): 553-558.

8. Benbott A, Yahyia A, Belaidi A, Assessment of the antibacterial activity of crude alkaloids extracted from seeds and roots of the plant Peganum harmala L. $J$ Nat Prod Plant Resour., 2012; 2(5): 568-573.

9. Bisset NG, Herbal drugs and phytopharmaceuticals: a handbook for practice on a scientific basis. $3^{\text {rd }}$ edition. London: CRC Press 1994; 556p.

10. Cascioferro S, Cusimano MG, Schillaci D, Antiadhesion agents against Gram-positive pathogens. Fut Microbiol., 2014; 9(10): 1209-1220.
11. Chlopicka J, Pasko P, Gorinstein S, Jedryas A, Zagrodzki P, Total phenolic and total flavonoid content, antioxidant activity and sensory evaluation of pseudocereal breads. LWT-Food Sci Technol., 2012; 46(2): 548-555.

12. Cos P, Ying L, Calomme M, Hu JP, Cimanga K, Poel BV, Pieters L, Vlietinck AJ, Berghe, Vanden $\mathrm{D}$, Structure-activity relationship and classification of flavonoids as inhibitors of xanthine oxidase and superoxide scavengers. J Nat Prod., 1998; 61(1): 71-76.

13. Crisan G, Vlase L, Balica G, Muntean D, Stefanescu C, Paltinean R, Tamas M, Leucuta S, LC/MS analysis of aucubin and catalpol of some Veronica species. Farmacia, 2010; 58(2): 237-247.

14. Da Silva E, Shahgaldian P, Coleman AW, Haemolytic properties of some water-soluble para sulphonatocalix-[n]-arenes. Int J Pharm., 2004; 273(1-2): 57-62.

15. Dilas S, Canadanovic-Brunet J, Cetkovic G, By-products of fruits processing as a source of phytochemicals. Chem Ind Chem Engineer Q, 2009; 15(4): 191-202.

16. Dua VK, Verma G, Singh B, Rajan A, Bagai U, Agarwal DD, Gupta NC, Kumar S, Rastogi A, Anti-malarial property of steroidal alkaloid conessine isolated from the bark of Holarrhena antidysenterica. Malaria J., 2013; 12(1): 194: 1-6.

17. Emsen B, The antioxidant and antigenotoxic potential of Peltigera canina and Umbilicaria nylanderiana based on their phenolic profile, Farmacia, 2019; 67(5): 912-921.

18. Ferrali M, Signorini C, Caciotti B, Sugherini L, Ciccoli L, Giachetti D, Comport M, Protection against oxidative damage of erythrocyte membrane by the flavonoid quercetin and its relation to iron chelating activity. FEBS Lett., 1997; 416(2): 123-129.

19. Harborne JB, Phytochemical methods: A guide to modern techniques of plant analysis. Chapman and Hall, London 1973: 279-282.

20. $\mathrm{Hu} \mathrm{Q}, \mathrm{Hu} \mathrm{Y}, \mathrm{Xu}$ J, Free radical-scavenging activity of Aloe vera (Aloe barbadensis Miller) extracts by supercritical carbon dioxide extraction. Food Chem., 2005; 91(1): 85-90.

21. Imida K, Promoting activities of butylated hydroxyanisole and butylated hydroxytoluene on 2-stage urinary bladder carcinogenesis and inhibition of $\alpha$-glutamyl transpeptidase-positive foci development in the liver of rats. Carcinogenesis, 1983; 4: 885-889.

22. Ito N, Hirose M, Fukushima S, Tsuda H, Shirai T, Tatematsu M, Studies on antioxidants: their carcinogenic and modifying effects on chemical carcinogenesis. Food Chem Toxicol., 1986; 24(10-11): 1071-1082.

23. Kaper JB, Nataro JP, Mobley HL, Pathogenic Escherichia coli. Nat Rev Microbiol., 2004; 2(2): 123-140.

24. Kolar P, Shen JW, Tsuboi A, Ishikawa T, Solvent selection for pharmaceuticals. Fluid Phase Equilibria, 2002; 194: 771-782.

25. Krishnaraju AV, Rao TV, Sundararaju D, Vanisree M, Tsay HS, Subbaraju GV, Assessment of bioactivity of Indian medicinal plants using brine shrimp (Artemia salina) lethality assay. Int J Appl Sci Eng., 2005; 3(2): 125-134.

26. Kusumoto IT, Nakabayashi T, Kida H, Miyashiro H, Hattori M, Namba T, Shimotohno K, Screening of various plant extracts used in ayurvedic medicine for inhibitory effects on human immunodeficiency virus 
FARMACIA, 2021, Vol. 69, 6

type 1 (HIV-1) protease. Phytother Res., 1995; 9(3): 180-184.

27. Lagha R, Ben Abdallah F, AL-Sarhan BO, ALSarhan BO, Al-Sodany Y, Antibacterial and Biofilm inhibitory activity of medicinal plant essential oils against Escherichia coli isolated from UTI patients. Molecules, 2019; 24(6): 1161: 1-12.

28. Lai EY, Chyau CC, Mau JL, Chen CC, Lai YJ, Shih $\mathrm{CF}$, Lin LL, Antimicrobial activity and cytotoxicity of the essential oil of Curcuma zedoaria. Am J Chin Med., 2004; 32(02): 281-290.

29. Li HB, Wong CC, Cheng KW, Chen F, Antioxidant properties in vitro and total phenolic contents in methanol extracts from medicinal plants. LWT-Food Sci Technol., 2008; 41(3): 385-390.

30. Magid AA, Schmitt M, Prin PC, Pasquier L, Voutquenne-Nazabadioko L, In Vitro Tyrosinase Inhibitory and Antioxidant Activities of Extracts and Constituents of Paeonia lactiflora Pall. Flowers. The Nat Prod J., 2017; 7(3): 237-245.

31. Moniruzzaman M, Rokeya B, Ahmed S, Bhowmik A, Khalil M, Gan S, In vitro antioxidant effects of Aloe barbadensis Miller extracts and the potential role of these extracts as antidiabetic and antilipidemic agents on streptozotocin-induced type 2 diabetic model rats. Molecules, 2012; 17(11): 12851-12867.

32. Moyo M, Ndhlala AR, Finnie JF, Van Staden J, Phenolic composition, antioxidant and acetylcholinesterase inhibitory activities of Sclerocarya birrea and Harpephyllum caffrum (Anacardiaceae) extracts. Food Chem., 2010; 123(1): 69-76.

33. Newman DJ, Cragg GM, Snader KM, Natural products as sources of new drugs over the period 1981-2002. J Nat Prod., 2003; 66(7): 1022-1037.

34. Orsine JVC, da Costa RV, da Silva RC, Santos MF, Almeida M, Novaes MRCG, The acute cytotoxicity and lethal concentration (LC50) of Agaricus sylvaticus through hemolytic activity on human erythrocyte. Int J Nut Met., 2012; 4(1): 19-23.

35. Petti S, Scully C, Polyphenols, oral health and disease: A review. J Dent., 2009; 37(6): 413-423.

36. Pham HNT, Vuong QV, Bowyer MC, Van Staden J, Effect of extraction solvents and thermal drying methods on bioactive compounds and antioxidant properties of Catharanthus roseus (L.) G. Don (Patricia White cultivar). J Food Proc Preser., 2017; 41(5): e13199: 1-8

37. Poli G, Leonarduzzi G, Biasi F, Chiarpotto E, Oxidative stress and cell signaling. Curr Med Chem., 2004; 11(9): 1163-1182.

38. Prasad S, Kashyap RS, Deopujari JY, Purohit HJ, Taori GM, Daginawala HF, Effect of Fagonia arabica (Dhamasa) on in vitro thrombolysis. BMC Compl Altern Med., 2007; 7(1): 36: 1-6.

39. Proestots C, Lytoudi K, Mavromelanidou O, Zoumpoulakis P, Sinanoglou V, Antioxidant capacity of selected plant extracts and their essential oils. Antioxidants, 2013; 2(1): 11-22.

40. Rice-Evans CA, Miller NJ, Paganga G, Structureantioxidant activity relationships of flavonoids and phenolic acids. Free Rad Biol Med., 1996; 20(7): 933-956.

41. Roshan R, Ahmed S, Hasan MM, Arisaema jacquemontii Blume (Araceae): A review of medicinal uses, phytochemistry and pharmacology. J Pharmacogn Phytochem., 2017; 6: 429-342.

42. Sahraei S, Mohkami Z, Golshani F, Javadian F, Saeidi S, Baigi GS, Antibacterial activity of five medicinal plant extracts against some human bacteria. Euro $J$ Exp Bio., 2014; 4: 194-196.

43. Saritha V, Anilakumar K, Khanum F, Antioxidant and antibacterial activity of Aloe vera gel extracts. Int $J$ Pharm Biolog Arch., 2010; 1(4): 376-384.

44. Shabbir A, Cox A, Rodriguez-Menocal L, Salgado M, Badiavas EV, Mesenchymal stem cell exosomes induce proliferation and migration of normal and chronic wound fibroblasts, and enhance angiogenesis in vitro. Stem Cells Develop., 2015; 24(14): 1635-1647.

45. Shahid SA, Anwar F, Shahid M, Majeed N, Azam A, Bashir M, Amin M, Mahmood Z, Shakir I, LaserAssisted synthesis of $\mathrm{Mn} 0.50 \mathrm{Zn} \quad 0.50 \quad \mathrm{Fe}_{2} \mathrm{O}_{4}$ nanomaterial: characterization and in vitro inhibition activity towards Bacillus subtilis biofilm. J Nanomater., 2015; 16(1): 111: 1-6.

46. Shahidi F, Ambigaipalan P, Phenolics and polyphenolics in foods, beverages and spices: Antioxidant activity and health effects - A review. J Funct Foods., 2015; 18: 820-897.

47. Shinkovenko IL, Kashpur NV, Ilyina TV, Kovalyova AM, Goryacha OV, Koshovyi OM, Kryvoruchko OV, Komissarenko AM, The immunomodulatory activity of ethanolic extracts from Galium verum L. herb. Ceska Slov Farm., 2018; 67: 101-106.

48. Souto AL, Tavares JF, Da Silva MS, Diniz MFFM, Da Athayde-Filho, PF, Filho JMB, Anti-inflammatory activity of alkaloids: an update from 2000 to 2010 . Molecules, 2011; 16(10): 8515-834.

49. Stankovic MS, Total phenolic content, flavonoid concentration and antioxidant activity of Marrubium peregrinum L. extracts. Kragujevac J Sci., 2011; 33(2011): 63-72.

50. Wu H, Moser C, Wang HZ, Hoiby N, Song ZJ, Strategies for combating bacterial biofilm infections. Int J Oral Sci., 2015; 7(1): 1-7.

51. Yadav R, Agarwala M, Phytochemical analysis of some medicinal plants. J Phytol., 2011; 3(12): 10-14.

52. Yang L, Meng Y, Peng D, Nie Z, Sun H, Molecular phylogeny of Galium L. of the tribe Rubieae (Rubiaceae) - emphasis on Chinese species and recognition of a new genus Pseudogalium. Mol Phylogenet Evolut., 2018; 126: 221-232. 